\title{
Potential Collection Development Bias: Some Evidence on a Controversial Topic in California
}

Dave Harmeyer

Using an unobtrusive quantitative method, this study investigates whether there is a bias in recent collection development practices at academic and public libraries in California. Influenced by Asheim's article "Not Censorship, but Selection" and Fiske's landmark 1957 California study, Book Selection and Censorship, the investigator applies a research method involving ten judges and the Online Computer Library Center's (OCLC) database holdings for eight representative books. These books (portraying a spectrum along the prochoice/pro-life abortion controversy) are used to demonstrate that the collection development activities of academic and public libraries in California appear to have a bias. Based on 580 reported holdings of these eight books, California academic and public libraries were found three times more likely to collect pro-choice than pro-life books. Interestingly, the evidence also shows that, comparatively, collection practices of religious-affiliated academic libraries in California appear to result in collections holding only slightly more representative pro-life books than pro-choice ones. Therefore, a conclusion may be inferred that stereotypical "conservative" libraries are doing a better job of providing different points of view on controversial issues than their "secular" institutional counterparts.

ibrarians in college, research, and public libraries in the United States are charged by their professional standards to endorse the ethical principle that "libraries should provide materials and information presenting all points of view on current and historical issues." ${ }^{11}$ The Library Bill of Rights, the idea of intellectual freedom, and other professional pronouncements provide librarians and information scientists with basic policies and guidelines for carrying out sound collection development practices.

There is, however, a growing concern that librarians may not be the impartial, tolerant developers of collections the profession requires that they must be. Ray Smith, former director of Mason City (Iowa) Public Library states, "Most censorship in libraries has probably been quietly accomplished by librarians themselves, through rejection of potentially controversial books. ${ }^{2}$ Cal Thomas,

Dave Harmeyer is an MLS graduate, class of 1993, of the Graduate School of Library and Information Science, University of California, Los Angeles, California 90024-1250 and is Acting Library Director at the International School of Theology, San Bernardino, California 92414-0001; e-mail dharmey@eis.calstate.edu or dharmey@chello.gina.calstate.edu. The author wishes to express his appreciation for the editorial remarks made by Donald Case, Art Hurtado, Beverly P. Lynch, Larry Marshburn, John Richardson, Meg Scheller, Gary Stanley, Joette Whims, and two anonymous referees. 
a thirty-one-year veteran of broadcast journalism and a columnist for the Los Angeles Times syndicate, has suggested that public libraries tend to develop collections weak in conservative alternatives to a wide range of social issues. ${ }^{3}$ If true, librarians may be guilty of what Lee Burress labels secret censorship and what others call precensorship - the act of restricting materials from a library collection by collection development librarians or other appropriate authorities because of conscious or subconscious personal social/political bias. ${ }^{4}$

A large body of literature exists on the traditional notion of censorship that generally means persons or groups requesting the restriction of information after it has become available to information users. Interestingly, little has been published recently on the topic of collection development bias - the restriction of resources by librarians before they become available to information users. Yet such bias in collection development raises questions of how book selection affects library constituents. Suppose a first-year college student is required to do a research paper on a current controversial topic. Will the student get a reasonable number of sources describing differing points of view by accessing books in a local college, university, or public library? A related issue concerns the possible social bias of religious-affiliated or perceived "conservative" academic libraries. For instance, do Protestant and Catholic educational institutions have a conservative collection development bias? The key research question of this study is: For a chosen controversial issue, what do California librarians appear to be practicing-selection or censorship?

Obviously, all conscientious collection development practitioners strive to be fair selectors and not censors. Nonetheless, this study provides some preliminary evidence, that overt selection bias may be prevalent in the American academic and public library community. Because of the investigator's commitment to presenting all points of view and community concerns regarding what materials and information are available to academic and public library users, the objective of this investigation is to develop an unobtrusive method for measuring collection development bias in California academic and public libraries.

More specifically, two null hypotheses were developed for the study and tested at the .01 level of significance. They are:

- There is no significant difference between the number of representative pro-choice books and pro-life books selected by California academic and public librarians.

- There is no significant difference between the number of representative pro-choice books and pro-life books selected by California librarians at religious-affiliated institutions.

\section{REVIEW OF RELEVANT LITERATURE}

One notable essay in library and information science literature that long has earned the reputation of helping librarians distinguish between selection and censorship is Lester Asheim's 1953 classic article, "Not Censorship, but Selection. ${ }^{\prime 5}$ Eric Moon's introduction to Book Selection and Censorship in the Sixties cites Asheim's essay as the standard reply for concerns about collection development improprieties. ${ }^{6}$ Furthermore, LeRoy Merritt, then dean at Oregon's School of Librarianship, in his Book Selection and Intellectual Freedom, also affirms Asheim's distinction between selection and censorship and supports his philosophy of collection development as something to be "completely understood, felt, and believed" if librarians are to stand up to censorship.? In brief, Asheim's work clarifies the librarian's motives and makes an important distinction between a censor and a selector. He says that librarians assigned to collection development will be selectors as long as they follow "good" motives. "Good" motives include a positive approach where the selector "looks for values, for strengths, for virtues which will overshadow minor objections" in the selection of works. ${ }^{8}$

Another earlier effort that surveyed the collection development bias of librarians continues to provide some vex- 
ing concerns for the library profession. In 1957, Marjorie Fiske, a Berkeley sociologist, published her findings concerning the presence of censorship in the collection development practices of school and public librarians in California. Through interviews, she surveyed 204 California school and public librarians and administrators. ${ }^{9}$ Her evidence showed that collection development librarians were engaged in what she recognized as "conscious" and "subconscious" censorship. ${ }^{10}$ In the area of conscious censorship, almost two-thirds of all librarians involved in selection development said that the controversial nature of a book or its author could result in the book not being purchased. Although nearly one-half of the librarians in her study expressed a commitment to the idea of freedom-to-read, "The rest were divided between those whose doctrine [was] clearly restrictive and those who express[ed] weak, wavering, or contradictory opinions. . . ."11 Even among those with freedom-to-read convictions, subconscious censorship was held by fully " 40 per cent [who] take controversiality into account under some circumstances, particularly if another, more 'legitimate,' reason can be found for avoiding a book."12

Thus, the issue of restrictive selection by librarians is not a recent topic. Book Selection and Censorship in the Sixties, edited by Eric Moon, leads off with a first chapter on "Book Rejection: Is It Censorship?"13 Therein, the editor asked eight public and university librarians how a librarian can decide not to add a controversial book to a collection without participating in censorship. A librarian may justify the rejection of a work for the following four reasons (in no particular order): legal, financial, standards of selection, or library policy. ${ }^{14}$

Both the academic and public sectors of the library profession have expressed contempt for any form of censorship in collection development. Robert Downs, then dean of Library Administration at the University of Illinois Libraries, Urbana, did not believe that the selection issue exerted the same pressures for academic librarians as it did for public librarians because, he reasoned, "university faculty members and students thrive on controversy."15 In defense of the public library's intolerance for selection bias, Stuart Sherman, librarian of Providence Public Library in Rhode Island, held that "objectivity on the part of the librarian [doing selection] is essential. A book must never be rejected because our opinion persuades us that it inappropriate." 16

Discussion of collection development bias within the last ten years is often couched among past debates on censorship. Published in 1985, Censorship: Opposing Viewpoints devotes one chapter out of seven to the topic "Is School and Library Censorship Justified?" Three of the essays touch on selection bias. In one article, Phyllis Schlafly, a conservative political activist, argues not so much for censorship as against what she calls "preemptive censorship," the exclusion of some books over others by librarians, teachers, and school administrators. ${ }^{17}$ Another essay, the "Freedom to Read Statement," adopted June 25, 1953, and revised January 28, 1972, by the American Library Association (ALA), declares that librarians should present all points of view. It further states that publishers, librarians, and booksellers conflict with the public's interest when they "establish their own political, moral, or aesthetic view as a standard for determining what books should be published or circulated."18 This ALA statement affirms the principle of freedom-to-read where selectors are to include works diverse in thought and expression.

Some authors have proposed deeper causes of collection development bias. In Book Burning (1983), developed out of a speech delivered to ALA in the summer of 1982, Cal Thomas addresses the reason conservative religious books are consistently left off bestseller lists and library bookshelves. He begins by documenting how schools, public libraries, and general bookstores discriminate against materials that contain a traditional conservative perspective. Specifically, for example, Thomas hopes 
that in public libraries, teenagers could find serious popular works teaching sexual abstinence or adoption as a preferred option for an undesired pregnancy.19 But, according to Thomas, a so-called credibility gap prevents materials with a religious conservative view from being reviewed and from being placed on welladvertised book lists, despite large volume sales. In a chapter "At the Back of the Bus in the New Negro League," Thomas associates the barrier between conservative "religious publishing" and its major league equivalents with the racial barrier in baseball broken by Branch Richey and Bill Veeck. ${ }^{20}$ Thomas believes that an anticonservative bias is the motive behind major league reviewers' unwillingness to acknowledge works from a conservative position or even to admit that a moral traditional view may have something worthwhile to add to the marketplace of publishing.

Released in the fall of 1991, Jill Carlson's What Are Your Kids Reading?: The Alarming Trend in Today's Teen Literature discusses some of the same themes as Thomas' work (e.g., conservative book discrimination and book review selection bias). While Carlson does not discuss traditional censorship, she does cover selection bias and the lack of conservative religious works in library collections. Carlson describes biases in the book review and the book promotion industries and argues that publishing firms consistently exclude books with conservative Christian viewpoints. As a result, conservative religious literature rarely gets into the mainstream collection process except by the narrow path of a patron's request or by the sheer volume of sales. For example, Frank Peretti's powerful fiction, This Present Darkness (Crossway Books, 1986), "sold nearly a million copies before some libraries knew it existed." 21 Other large-sale authors-whose books outsell their less conservative competition, but do not appear in major book review magazines or bestseller lists-include the popular teen fiction of Bodie Thoene and Steven Lawhead. ${ }^{22}$

Although the effect of book reviews is not the primary focus of this discussion, it has been shown that fewer reviews of a title during the book reviewing process ultimately do affect selection. Judy Serebnick, in her insightful dissertation "Relationship between Book Reviews and Inclusion of Potentially Controversial Books in Public Libraries," found that "books with a greater number of reviews were owned by significantly more libraries than were books with a lower number of reviews." 23

Today, librarians involved in collection development continue to be guided by Asheim's forty-year-old "not censorship, but selection" mandate. His ideas have been augmented by the Library Bill of Rights and amplified in publications issued by ALA's Office for Intellectual Freedom. However, Fiske and others have asserted that some librarians do practice censorship-a disturbing finding.

In summary, three conditions exist concerning the question of acquisition bias in libraries: (1) growing accusations of collection development bias, (2) a public policy committed to presenting all points of view on current and historical issues, and ( 3 ) emerging community concerns about the kinds of information accessible to children, students, and all users. Because of these considerations, the investigator has designed an unobtrusive method for quantitatively documenting possible selection bias in academic and public libraries. This topic is important because conscious or subconscious selection bias and discrimination should not be tolerated by the library profession whether it comes from the political/social left or the conservative/religious right. In addition, the thirty-five-year period since Fiske's 1957 study demands an update on the prevalence of collection development bias not only in public but also academic libraries.

\section{METHOD OF INVESTIGATION}

This investigation, conducted in the late fall of 1992, was carried out in five stages: (1) selecting a controversial topic that could provide evidence for collection development bias; (2) identifying representative works on the chosen topic; (3) ranking of representative works 
by qualified judges; (4) measuring holdings by use of the Online Computer Library Center's (OCLC) database (believed to be the first published use of this technique); and (5) analyzing the holdings data.

\section{A Controversial Topic}

The topic of pro-choice versus pro-life was selected because it is a contemporary social controversy related to the broader abortion issue and has two clear and distinct camps. In this study, prochoice refers to the movement advocating the right of women to choose an abortion without legal restrictions while pro-life is the movement in favor of legally restricting the termination of the life of the fetus. Other reasons for selecting this topic are that qualified judges easily could be solicited and the issue is powerful enough to show potential selection bias.

\section{Selection of the Works}

Eight representative books were chosen using University of California's MELVYL and UCLA's ORION electronic catalogs and some public card catalogs (looking under the Library of Congress subject headings of "pro-choice movement" and "pro-life movement") as well as browsing collections. ${ }^{24}$ Three works initially were determined to be prochoice, three as pro-life, and two that seemed to address both sides of the issue. These eight titles were considered a reasonable number of books one could expect willing respondents to judge within thirty minutes. In addition, each book was assigned a random number to minimize any bias during the handling of books and to simplify the recording of judges' decisions.

Works were chosen based on four additional criteria:

- Possible availability in public and academic libraries (i.e., hardback, popular reading level, nonscholarly);

- Number of book reviews (ranging from 0 to 12, Abortion: Pro-Choice or Pro-Life? was the only one with no book reviews but was included to represent a recent work);
- Currency (from 1981 to 1992, except Handbook on Abortion - explained below); and

- The sense of being a "classic" (i.e., Handbook on Abortion).

This investigation was not designed to select the "plain vanilla collection" type of books (i.e., titles held by most libraries). Instead, the above criteria are intended to eliminate those works that may have been criticized as not likely to be in the libraries under investigation. Reasonable effort was taken to choose eight works that one would expect to find in public and academic library collections. Also, it is not clear whether a larger sample of books would have provided different or more valid results. Nevertheless, study limitations require such a larger sampling to be carried out by other investigations.

\section{Ranking of Works by Judges}

Judges were chosen for their affiliation with the pro-life or pro-choice movements. They either had given public talks on their views or were referrals from others active on the issue in their communities. Seven of the ten judges held or were working on graduate degrees (three earned doctorates were represented on the pro-choice side versus three graduate degrees and one doctorate on the pro-life side). Four of the judges, two in each camp, had recently been or were presently active in their side of the movement such as directing a pro-life pregnancy counseling center or representing a local pro-choice organization. Individual interviews took place within a small geographical area. The furthest distance between any two judges' interview locations was about twelve miles. Gender distribution of judges for both sides included four females and one male. Each participant was told that the investigation related to the prochoice/pro-life issue and that their identities would remain confidential.

In an attempt to establish a distributed book sequence that is fair, judges were asked to "score" each book by placing it on a seven-point Likert scale (see figure 1). 


\begin{tabular}{|c|c|c|c|c|c|c|}
\hline $\begin{array}{c}\text { Very } \\
\text { Pro-life }\end{array}$ & & & $\begin{array}{c}\text { Neutral } \\
\text { or Both }\end{array}$ & & & $\begin{array}{c}\text { Very } \\
\text { Pro-choice }\end{array}$ \\
\hline $3^{*}$ & 2 & 1 & 0 & 1 & 2 & 3 \\
\hline
\end{tabular}

* Numbers refer to point values

\section{FIGURE 1}

Scale Judges Used for Scoring Each Book

Each heading (Very Pro-choice, etc.) and number $(3,2,1,0)$ were written on a $3 \times 5$ card and placed in front of the judges. In this way, the scoring instrument was adapted for each participant while minimizing bias by the instrument. For example, a pro-choice judge would have seen "Very Pro-choice" to his or her left and "Very Pro-life" to his or her right and vice versa for a pro-life judge.

The investigator visited all ten judges individually and instructed them to scan each book, determine the work's perspective using the scale, and place each book on the scale. Each judge finished the scoring within thirty minutes. The investigator did not ask judges if they had previously seen or read any of the books. However, during the scoring, four judges (two from each side) revealed that they were familiar with several works. ${ }^{25}$ According to statistical analysis, the judges (on the whole) rated the group of eight books, overall, as just slightly more pro-life. ${ }^{26}$ This shows the investigator's effort in selecting a set of works that, taken as a whole, represent both points of view. For more detailed results of the ten judges' scores, see table 1.

\section{Measuring Holdings}

To test the effects of collection development bias in California, library holdings data were measured by analyzing OCLC's database on the eight books in November 1992. As an OCLC memberlibrary produces a record of a book, the library's three-character institutional symbol is added to the book's OCLC master record. In this way, each master record contains an account of OCLC member-libraries owning at least one copy. Each three-character symbol, therefore, represents a measurable decision in the collection development process of that OCLC member-library. Of the approximately 1,029 academic and public libraries and branches in California, 460 were OCLC member-libraries. ${ }^{27}$ At the time of this investigation, OCLC's database contained over 24.8 million records; thus, the database provides a broad-

TABLE 1

JUDGMENTS MADE OF THE EIGHT BOOKS ALONG A PRO-LIFE/PRO-CHOICE ORIENTATION

\begin{tabular}{|c|c|c|c|c|c|c|c|}
\hline Books & $\begin{array}{c}\text { Very } \\
\text { Pro-life } \\
3\end{array}$ & 2 & 1 & $\begin{array}{c}\text { Neutral } \\
\text { or Both } \\
0\end{array}$ & 1 & 2 & $\begin{array}{c}\text { Very } \\
\text { Pro-choice } \\
3\end{array}$ \\
\hline 1. Crusaders & & & & 2 & 4 & 4 & \\
\hline 2. Our Right to Choose & & & & & 3 & 7 & \\
\hline 3. Enemies of Choice & & & & & 2 & 3 & 5 \\
\hline 4. Abortion & 1 & 1 & 1 & 5 & & 2 & \\
\hline 5. I Will Never Forget You & 10 & & & $\smile$ & & & \\
\hline 6. Closed & 10 & & & & & & \\
\hline 7. The Right-to-Lifers & & & 2 & & 2 & 5 & 1 \\
\hline 8. Handbook on Abortion & 8 & 1 & 1 & & & & \\
\hline
\end{tabular}


TABLE 2

LIBRARY UNITS BY TYPE OF LIBRARY

\begin{tabular}{lrrrrrrrrrr}
\hline & \multicolumn{8}{c}{ Orientation of Texts } \\
\cline { 2 - 8 } & \multicolumn{3}{c}{ Very Pro-life } & \multicolumn{1}{c}{$\begin{array}{c}\text { Neutral } \\
\text { or Both }\end{array}$} & Pro-choice & Very Pro-choice & \\
\cline { 2 - 9 } Library Type & $5^{*}$ & 6 & 8 & 4 & 1 & 7 & 3 & 2 & Totals \\
\hline Academic & 6 & 9 & 25 & 12 & 37 & 44 & 33 & 47 & 213 \\
Public & 5 & 41 & 40 & 2 & 61 & 86 & 34 & 61 & 330 \\
Religious-affiliated & 2 & 5 & 15 & 0 & 1 & 0 & 3 & 11 & 37 \\
Totals & 13 & 55 & 80 & 14 & 99 & 130 & 70 & 119 & 580 \\
\hline
\end{tabular}

* Numbers (5, 6, 8 etc.) refer to books listed in table 1.

based picture of library holdings within California. ${ }^{28}$

Any of the 460 libraries could own from none to all eight of the titles plus any subsequent editions and copies. According to OCLC's database, the total number of OCLC three-character symbols (of academic and public libraries) in California attached to the master records representing all eight books was 580 (see table 2). ${ }^{29}$ This value will be called a "library unit" to distinguish it from the incorrect assumption that the number represents 580 separate libraries. For this study the value can be viewed as choices made by those involved in collection development.

The two hypotheses mentioned above were tested by classifying the libraries into three types: (1) academic, (2) public, and (3) religious-affiliated (college and above). Because of the second hypothesis, religious-affiliated libraries (a set within the academic division) were placed as a third category to detect possible bias in collection development. The following institutions are examples of each library type: (1) academic-California State University, Chico; (2) public-Torrance Public Library; (3) religious affiliated-Saint John's Seminary. Libraries were classified by "type" using the OCLC Participating Institutions: Arranged by OCLC Symbol publication schedule. ${ }^{30}$ Unclear names (e.g., Santa Clara University, a Catholic institution) were verified in the 1987-88 Directory of Postsecondary Institutions. $^{31}$
Only one state, California, was selected for measuring holdings data for the following reasons. First, California provided comparative data for the findings of Fiske's 1957 study on selection bias. Second, time constraints prevented an exhaustive tabulation of all United States library units (about 5,600 ) of the eight books. Third, California had the largest number of library units (580) for the total eight works (the next being New York state with 511 library units). Fourth, the investigator was more familiar with California's institutional and geographical names (for establishing the three types of libraries) than those of other states. Fifth, California is likely to typify other states in light of the topic: possible academic, public, and religiousaffiliated library selection bias of prolife/pro-choice books.

Even with such large numbers, the investigator acknowledges that some academic and public California libraries owning one or more of the works will not be included in the findings. Libraries may not catalog some inhouse materials for an extended time because of backlog. Because there are many other techniques for creating records (both electronic and nonelectronic), it is possible to process a book inhouse and not have it recorded in a national utility (like OCLC). Also, some California libraries are members of online bibliographic networks other than OCLC, such as Stanford University's Research Libraries Information Network (RLIN), and thus would not have their library holdings recorded in OCLC. 
TABLE 3

COMBINED LIBRARY UNITS BY TYPE OF LIBRARY

\begin{tabular}{lccc}
\hline & \multicolumn{3}{c}{ Orientation of Texts } \\
\cline { 2 - 4 } Library Type & Pro-life & Pro-choice & Totals \\
\hline Academic and public & 126 & 403 & 529 \\
Religious-affiliated & 22 & 15 & 37 \\
Totals & 148 & 418 & 566 \\
\hline
\end{tabular}

$x^{2}=20.94 ; \propto=.01$

In addition, the data from OCLC do not reflect multiple copies of each of the eight books owned by member-libraries. However, this investigation regards multiple copies as a minor measure of the collection development process. What is important is the fact that at least one copy of the representative books was chosen to be added to a library's collection. Despite these limitations, the data do suggest that many California libraries are members of OCLC and a significant number of OCLC member-libraries chose to own at least one of the eight books.

In an attempt to verify record accuracy, twenty OCLC member-libraries in the study were contacted. Ten libraries in Southern California were visited (three academic, four public, and three religious-affiliated). Ten randomly chosen libraries throughout the state were contacted by phone (four academic, five public, and one religious-affiliated). After searching ten local electronic or card catalogs and browsing their stack areas, the investigator discovered no discrepancies between OCLC's database and what was found-except books that were checked out. There were no cases where a representative book was found in a local catalog or on a shelf that was not also reflected in OCLC. Various answers were given by reference librarians or catalogers at the ten other libraries when asked, "Does OCLC reflect what you have in your collection?" Six said yes; while four others were not sure or reported that everything should be in OCLC except fiction and children's works. All ten respondents checked their catalogs for the two oldest books in the study: Willke's 1971 Handbook on Abortion (including edi- tions) and Merton's 1981 Enemies of Choice. Again, there were no differences between what was reported and what was reflected in OCLC's database.

\section{Analysis of Library Units Holdings}

Table 2 shows the number of libraries (i.e., library units) in California that reported holding each book, distributed among three library types (academic, public, and religious-affiliated). The orientations of the texts are along the prolife/pro-choice spectrum. For example, six academic libraries (library units) in California reported owning the pro-life work \#5 I Will Never Forget You.

Table 3 provides a simplification of table 2 for a chi-square analysis. Because Abortion: Pro-Choice or Pro-Life? (book \#4) was found by most judges to be "neutral or both," it was dropped out of the pro-life/pro-choice classification. Books judged as very pro-life (numbers 5, 6, and 8 ) were collapsed to form the pro-life category. Those books appraised as prochoice or very pro-choice (numbers 1,2 , 3 and 7) were combined to form the category of pro-choice. Types of libraries were reduced to two by collapsing academic and public into one category. Therefore, the number 126 in table 3 represents the total number of representative book choices (library units) with a pro-life orientation added to California academic and public OCLC member-libraries by collection development librarians.

\section{RESULTS}

As indicated above, the hypotheses concern the statistical relationship between the selection (by academic and public librarians) of pro-life books and 
pro-choice books based on a .01 level of significance adopted for this study. $\mathrm{Hy}$ pothesis one states:

- There is no significant difference between the number of representative pro-choice books and pro-life books selected by California academic and public librarians.

A chi-square value was calculated for the number of academic and public libraries (library units) holding the sample of pro-life books and those library units holding the sample of pro-choice books (see table 3). A chi-square of 20.94 was obtained, which is significant at better than the .001 level. ${ }^{32}$ Since the .01 level of significance was adopted for this study, hypothesis one can be rejected. Based on the evidence presented in this study, California academic and public libraries were more than three times as likely to report holding the sample prochoice books than the pro-life books.

As indicated above, the second hypothesis concerns the statistical relationship between the selection of pro-life books and pro-choice books by librarians at religious-affiliated institutions. Hypothesis two states:

- There is no significant difference between the number of representative pro-choice books and pro-life books selected by California librarians at religious-affiliated institutions.

The data collected to test hypothesis two also are given in table 3 . The calculated chi-square value is 20.94 which is statistically significant at the .01 level. Hypothesis two is also rejected. Religious-affiliated libraries were about 1.5 times as likely to report owning the prolife sample of books as they were the pro-choice titles.

\section{DISCUSSION AND IMPLICATIONS}

This investigation is based on the ranking of eight books by ten judges according to a pro-life/pro-choice scale and then measuring the books' holdings reported by OCLC's database in three types of California libraries. The results suggest that academic and public libraries in California contain collections biased in $\mathrm{fa}$ vor of the pro-choice side of the abor- tion controversy. Religious-affiliatedlibraries show having a pro-life bias but to a lesser degree than the academic and public libraries. As discussed in the literature review, Downs alleged that the university library does not have the same concerns about selection bias as public libraries because "university faculty members and students thrive on controversy." ${ }^{\prime 3}$ If so, then it appears the academic library community is not presenting fairly all points of view on this important topic for its faculty and student users.

Based on the above methodology and findings, this study assumes the appearance or nonappearance of the eight books is justification for inferring collection development bias. However, several factors could explain the skewed findings apart from direct selection bias. First, many conservative books that are critical of particular social phenomena (like the pro-choice movement) are simply not reviewed by standard book reviewing sources, as stated by Schlafly, Thomas, and Carson. In addition, collection development policies and limited budgets can present legitimate barriers for librarians striving to select for a collection that does present all points of view on issues. However, according to this study, patrons at religious-affiliated academic institutions (namely, Protestant, Catholic, and Jewish) profit intellectually and socially from fairer access to all points of view on the prochoice/pro-life controversy. Academic librarians at religious-affiliated institutions appear more in accord with the Library Bill of Rights (and Asheim's mandate) than their colleagues at secular academic and public libraries.

\section{FOR FURTHER INVESTIGATION}

For additional comparison, Fiske's study could be repeated to provide additional evidence to help refute or prove the suggestion of book selection bias found in the above inquiry. Naturally, the investigator is aware that this study only begins to quantify the large issue of collection development bias. Additional holdings data need to be collected and evaluated, including records from the 
other forty-nine states on the prochoice/pro-life topic. A similar unobtrusive investigation could be conducted on other contemporary social/political issues such as gay/lesbian/bisexual rights, feminism, fetal tissue experimentation, school-based clinics, political correctness, or gays in the military. The claim that quality conservative religious books, critical of liberal social movements, do not get reviewed by standard book reviewers should be studied. If verified, alternative guidelines should be developed for the professions involved to provide fairer representation of various points of view in reviews and, eventually, library collections.

\section{CONCLUSION}

This study uses an original, unobtrusive, quantitative method testing the holdings data of eight representative books spanning the pro-choice/pro-life controversy. The results infer there is a statistically significant pro-choice bias in the collection development practices of California academic and public libraries who use OCLC as their national utility. Although they tended to have slightly more pro-life titles, California religious-affiliated institutions (a subset of academic libraries) were found, as a group, to have a more equal distribution of the eight books. Based on the above findings, academic and public librarians appear to be involved in selection development processes that consciously or subconsciously discriminate against a conservative social/political perspective, in this case, the pro-life point of view. Consequently, it may be inferred that many California librarians are practicing selection bias and their libraries are not providing materials that fairly represent all points of view on this important social issue.

\section{REFERENCES AND NOTES}

1. Library Bill of Rights (Chicago: ALA, 1980).

2. Book Selection and Censorship in the Sixties, ed. Eric Moon (New York: Bowker, 1969), 17.

3. Cal Thomas, Book Burning (Westchester, Ill.: Crossway Bks., 1983), 22-25.

4. Lee Burress, Battle of the Books: Literary Censorship in the Public Schools 1950-1985 (Metuchen, N.J.: Scarecrow, 1989), 88; Thomas, Book Burning, 81.

5. Lester Asheim, "Not Censorship, but Selection," Wilson Library Bulletin 28 (Sept. 1953): 63-67.

6. Eric Moon, in Book Selection and Censorship, 3.

7. LeRoy Merritt, Book Selection and Intellectual Freedom (Bronx, N.Y.: Wilson, 1970), 12.

8. Asheim, "Not Censorship, but Selection," 66. However, is there a dilemma facing today's information profession with the attempt to redefine "good" motives in a cultural climate that progressively replaces the absolute values of Asheim's generation with more tolerant subjective ones?

9. Marjorie Fiske, Book Selection and Censorship: A Study of School and Public Libraries in California (Berkeley, Calif.: Univ. of California Pr., 1959), 2.

10. Merritt, Book Selection, 13.

11. Fiske, Book Selection and Censorship, 64.

12. Ibid., 65 .

13. Moon, Book Selection and Censorship, 12.

14. Ibid., 16-17. For example: legal-works representing treason, libel or pornography; financial-book budget limitations; standards of selection-absence of book standards such as authority of author, publisher reputation, literary style, clarity of expression, format; library policy - dependent on such general factors as library size and nature of the population being served.

15. Ibid., 21.

16. Ibid., 17.

17. Censorship: Opposing Viewpoints, ed. Terry O'Neill (St. Paul, Minn.: Greenhaven Pr., 1985), 140.

18. Ibid., 142. 
19. Thomas, Book Burning, 26. Although beyond the scope of this study, it would be interesting to test Thomas' ten-year-old claim. Do public libraries today collect popular teen books that seriously promote sexual abstinence and adoption?

20. Ibid., 101.

21. Jill Carlson, What Are Your Kids Reading? The Alarming Trend in Today's Teen Literature (Brentwood, Tenn.: Wolgemuth \& Hyatt, 1991), 31.

22. Ibid., 32-33.

23. Judy Serebnick, "The Relationship between Book Reviews and the Inclusion of Potentially Controversial Books in Public Libraries" (Ph.D. diss., Rutgers University, 1978), 185.

24. The following books are listed in the original random order as received by judges. Sequential numbers are references to tables 1 and 2: (1) Marian Faux, Crusaders: Voices from the Abortion Front (Secaucus, N.J.: Carol Publishing Group, 1990); (2) Beverly Wildung Harrison, Our Right to Choose: Toward a New Ethic of Abortion (Boston: Beacon, 1983); (3) Andrew Merton, Enemies of Choice: The Right-to-Life Movement and Its Threat to Abortion (Boston: Beacon, 1981); (4) Gary Crum and Thelma McCormack, Abortion: Pro-Choice or Pro-Life? (Washington, D.C.: American Univ. Pr., 1992); (5) Joan Andrews with John Cavanaugh-O'Keefe, I Will Never Forget You: The Rescue Movement in the Life of Joan Andrews (San Francisco: Ignatius, 1989); (6) Joseph M. Scheidler, Closed: 99 Ways to Stop Abortion (Westchester, Ill.: Crossway Bks., 1985); (7) Connie Paige, The Right-to-Lifers: Who They Are, How They Operate, Where They Get Their Money (New York: Summit, 1983); (8) Jack C. Willke, Handbook on Abortion (Cincinnati: Hiltz Publishing, 1971).

25. One interesting note: The judges consistently placed three of the works (\#5 I Will Never Forget You, \#6 Closed, and \#8 Handbook on Abortion) in the "very pro-life" category. Possible reasons for the agreement may be the nature of the pro-life issue, the similar development of thought of the pro-life writers, or the fault of the investigator for not locating a more diversified sample of pro-life works.

26. If each judgment is given a value along the 1-7 scale (for example \#1 Crusaders: $4 \times 2$ judgments $+5 \times 4$ judgments $+6 \times 4$ judgments $=52$ ) the total score comes to 306 for all judgments. When divided by the eight books the average is 38.25 which is only slightly to the left of the median 40 , i.e., slightly toward the pro-life side.

27. California Library Statistics 1991: Financial Year 1989-1990 Data from Public, Academic, Special and Country Law Libraries, ed. Collin Clark (Sacramento, Calif.: Library Development Service Bureau, 1991), 4-5; the California number $(n=460)$ is based on a phone call to OCLC's Pacific Network Marketing Department in Rancho Cucamonga, California.

28. OCLC Annual Report, 1991/92: Accessing New Worlds of Information (Dublin, Ohio: OCLC, 1992).

29. Six library units were not calculated in the total because they represented libraries other than academic, public, or religious-affiliated (e.g., a library at an air force base).

30. OCLC Participating Institutions: Arranged by OCLC Symbol (Dublin, Ohio: OCLC, 1992).

31. National Center for Education Statistics, 1987-88 Directory of Postsecondary Institutions vol. 1 (Washington, D.C.: Department of Education).

32. Chi-square was determined using the statistical analysis package EPISTAT, version 3.3. Tracy L. Gustafson, EPISTAT Services, 2011 Cap Rock Circle, Richardson, TX 75080-3417.

33. Moon, Book Selection and Censorship, 21. 


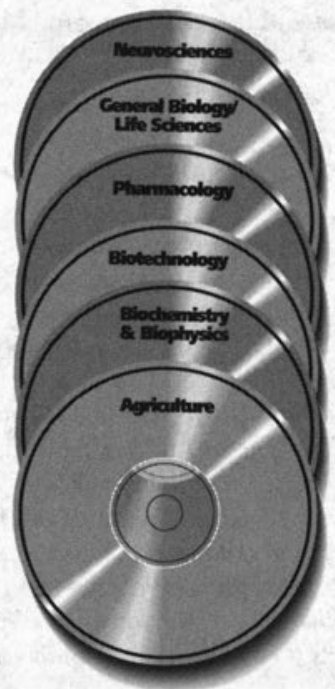

You could buy a collection of CDs in these areas...

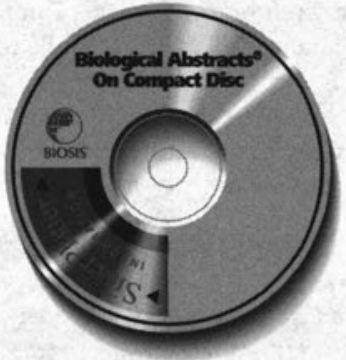

...and still not match the coverage found in Biological Âbstracts on Compact Disc.
$\mathbf{W}_{\text {t }}$ a single soch journal literature: Biological Abstracts on CD.

\section{Comprehensive Journal and Subject Coverage}

Nearly 6,500 international journals are monitored for Biological Abstracts on CD, so researchers can pinpoint relevant references quickly and easily. Biological Abstracts on CD's extensive multidisciplinary life science coverage enables you to direct a variety of researchers to this single, convenient source.

\section{A Smart Investment}

Biological Abstracts on CD eliminates the need to purchase costly single-subject publications that offer limited coverage. Plus, Biological Abstracts on CD employs SilverPlatter"s userfriendly software, so even novice searchers achieve optimum results.

\section{Call Now for a 30-Day Free Trial Disc! 1-800-523-4806 \\ (USA and Canada) (215) 587-4847 (Worldwide)}

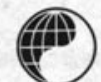

\section{BIOSIS $^{\circ}$}

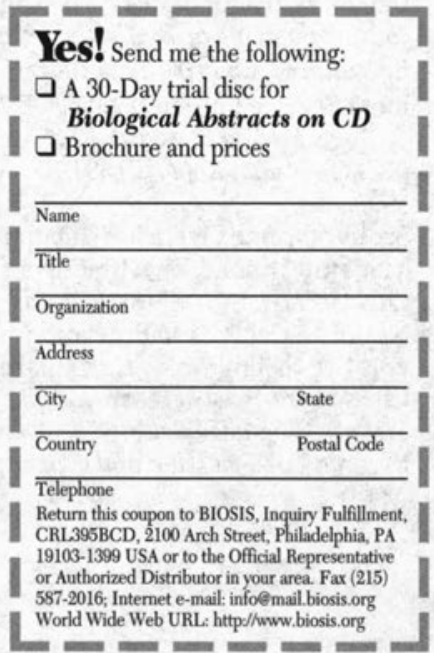

Information for Today's Decisions and Discoveries 